JUL 261955 



\title{
LIST OF PAPERS
}

\section{(1879-1906)}

BY

\section{WM. EAGLE CLARKE}

\author{
F.R.S.E., F.L.S., \&c.
}

ASSISTANT KEEPER, NATURAL HISTORY DEPARTMENT, ROYAL SCOTTISH MUSEUM ; CORRESPONDING FELLOW OF THE AMERICAN ORNITHOLOGISTS' UNION ; CORRESPONDIRENDEQ MITGLIED DES ORNITHOLOGISCHEN VEREINS IN WIEN ; MEMBRE HONORAIRE DU BUREAU CENTRAL ORNITHOLOGIQUE HONGROIS; MEMBER OF THE BRITISH ORNITHOLOGISTS' UNION, ETC. 
is 


\section{LIST OF PAPERS \\ (1879-1906)}

BY WM. EAGLE CLARKE, F.R.S.E., F.L.S., \&C.

Assistant Keeper, Natural History Department, R'oyal Scottish Museum; Corresponding Fellow of the American Ornithologists' Union; Correspondirender Mitglied des Ornithologischen Vereins in Wein; Membre honoraire ciu Bureau Central Ornithologique Hongrois; Member of the British Ornithologists' Union, etc.

\section{906 (January)}

Ornithological Results of the Scottish National Antarctic Expedition. II. On the Birds of the South Orkney Islands. The Ibis, I 906, pp. I 45-I87. Ten Plates and Map.

The Birds of Fair Isle, Native and Migratory. Ann. Scot. Nat. Hist., I906, pp. 4-2 I (to be continued). Plates I. and II.

\section{5}

On the House Mice of the Outer Hebrides. Ann. Scot. Nat. Hist., I 905, pp. I 98-I 99.

Ornithological Results of the Scottish National Antarctic Expedition. I. On the Birds of Gough Island, South Atlantic Ocean. The Ibis, I905, pp. 247-268. Plate VI. and Map.

The Birds of the Flannan Islands, Outer Hebrides. Ann. Scot. Nat. Hist., I905, pp. 8-19, 80-86, and Plates I. and II.

On the Vole and Shrew of the Orkney Islands. Ann. Scot. Nat. Hist., I 905, pp. I-8.

\section{4}

On Two Birds new to Science from Gough Island, South Atlantic Ocean. Bull. Brit. Orn. Club, xv. pp. I 8-i 9. On the Occurrence of the Short-toed Lark and Lapland Bunting in the Outer Hebrides. Ann. Scot. Nat. Hist., I 904, pp. 206-207.

On Some Forms of Mus musculus, Linn. With Description of a new Sub-species from the Faroe Islands. Proc. Roy. Phys. Soc. Edin., xv. pp. I 60- I67.

Studies in Bird Migration. II. The Results of Observations made at the Kentish Knock Lightship in the Autumn of 1903. The Ibis, I904, pp. I I 2-I 42, Plate IV. 



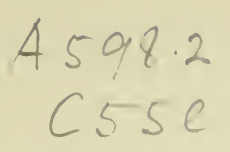

\section{Nul Resigt.}

Bird Migration in Great Britain and Ireland. Nature, vol. lxix. p. 5 I 6.

On the Occurrence of the Little Bunting (Emberiza pusilla) in Orkney. An Addition to the Scottish Avifauna. Ann. Scot. Nat. Hist., I 904, pp. I 4- I 5.

On Insects observed at the Eddystone Lighthouse in the Autumn of 1901. Entomologists' Monthly Magazine, I 904, pp. 9-I O.

\section{3}

Vanessa antiopa and other Insects at the Kentish Knock Lightship. Entomologists' Monthly Magazine, I903, pp. $289-290$.

Bird Migration in Great Britain and Ireland. Histories of the Migrations of the Starling (Sturmus vulgaris) and the Rook (Corvus frugilegus). Rep. Brit. Assn., I 903 , pp. 29 I-304.

Additional Notes on the Vertebrate Fauna of West Ross-shire. By Lionel W. Hinxman and WM. Eagle Clarke. Ann. Scot. Nat. Hist., I903, pp. 69-73.

On the Occurrence of Phylloscopus viridanus, Blyth, and other Interesting Birds at Scottish Light-stations. Ann. Scot. Nat. Hist., I903, pp. 22-25.

\section{2}

Bird Migration in Great Britain and Ireland. The Migrations of the Fieldfare (Turdus pilaris) and the Lapwing (Vanellus vulgaris). Rep. Brit. Assn., I902, pp. $274-283$.

A Month on the Eddystone. A Study in Bird Migration. The Ibis, I902, pp. 245-269. 



\section{90 I}

Bird Migration in Great Britain and Ireland. The Migrations of the Skylark (Alauda arvensis) and the Swallow (Hirundo rustica). Rep. Brit. Assn., I90 I, pp. 365-376.

On the Occurrence of Linota rostrata (Coues), a Greenland Redpoll, in Barra, Outer Hebrides. Ann. Scot. Nat. Hist., I 90 I, pp. I 3 I-I 32.

On Some Migratory and other Birds observed in Southern Shetland in September 1900. By WM. EAGLE Clarke and T. G. Laidlaw. Ann. Scot. Nat. Hist., I 90 I, Pp. I-I 2.

\section{900}

Bird Migration in Great Britain and Ireland. IOn the Migrations of the Song Thrush (Turdus musicus) and White Wagtail (Motacilla alba). Rep. Brit. Assn., I 900, pp. 403-4 I 3 .

On some Birds from the Island of Negros, Philippines. Part IV. With Description of Three Forms new to Science. The Ibis, 1900, pp. 35I-36I, Plate VIII.

The Fishes of the Firth of Forth and its Tributaries. No. II. Further Additions and Occurrences of Rare Species since Dr. Parnell's Essay of I 837. Ann. Scot. Nat. Hist., I 900, pp. 202-2 I 5.

The Fishes of the Firth of Forth and its Tributaries. Species added since Dr. Parnell's Essay of 1837. Ann. Scot. Nat. Hist., I 900, pp. 8-I 7.

\section{9}

On a White Phase in the Plumage of the Iceland Gull (Larus leucopterus). Proc. Roy. Phy's. Soc. Edin., xiv. pp. I $64-167$. 
Digitized by the Internet Archive in 2016 with funding from

University of Illinois Urbana-Champaign Alternates 
On the 0ccurrence of the Asiatic Houbara (Houbara macqueenii) in Scotland. Proc. Roy. Phys. Soc. Edin., xiv. pp. I62-I 63 .

On the 0ccurrence of the Lesser White-throat (Sylvia curruca) in the Outer Hebrides, with Remarks on the Species as a Scottish Bird. Proc. Roy. Phys. Soc. Edin., xiv. pp. I $58-\mathrm{I} 62$.

Ushant as an Ornithological Station. Notes on the Birds observed at Ushant and on the West Coast of Brittany, etc. The Ibis, pp. 246-270.

An Epitome of Dr. Walter's Ornithological Results of a Voyage to East Spitzbergen in the year 1889. The Ibis, I 899, pp. 42-5 I.

\section{8}

On the Ornithology of the Delta of the Rhone. Second contribution. The Ibis, I 898, pp. 465-485.

The Protection of Wild Birds and their Eggs in Scotland. Ann. Scot. Nat. Hist., I 898, pp. I 46- I 52.

On the Avifauna of Franz Josef Land. Including a Report on the Birds collected by the Jackson-Harmsworth Expedition. The Ibis, I 898, pp. 249-277, Map.

On Hybrids between the Capercaillie and the Pheasant. Ann. Scot. Nat. Hist., I 898, pp. I 7-2 I.

On some Birds from the Island of Negros, Philippines. Part III. The Ibis, I 898, pp. I I 9-I 24.

\section{7}

On the Occurrence of the Frigate Petrel (Pelagodroma marina) on the West Coast of Scotland. Ann. Scot. Nat. Hist., I 897, p. 88. 



\section{6}

Bird Migration in Great Britain and Ireland. A Digest of Observations on the Migrations of Birds at Lighthouses and Light-vessels, I 880-1887. Rep. Brit. Assn., I 896, pp. $452-477$.

\section{5}

On some Birds from the Island of Negros, Philippines. Second contribution. The Ibis, I 895, pp. 472-479.

On the Ornithology of the Delta of the Rhone. The Ibis, I 895, pp. I 73-2 I I, Map.

On the Recent Visitation of the Little Auk (Mergulus alle) to Scotland. Ann. Scot. Nat. Hist., I 895, pp. 97- Io8 and Map.

Some Fishes New to or Rare in the Firth of Forth. Ann. Scot. Nat. Hist., I 895, pp. 23-28.

\section{894}

On the probable Breeding of the Hawfinch (Coccothraustes vulgaris) in Midlothian. Ann. Scot. Nat. Hist., I 894, pp. 195-197.

On some Birds from the Island of Negros, Philippines. The Ibis, 1904, pp. 53 I-535.

A Contribution to the Vertebrate Fauna of West Rossshire. By Lionel IV. Hinxman, B.A., and W. Eagle Clarke. Proc. Roy. Phys. Soc. Edin., xii. pp. 377-4 I 5.

On the Persecution of the Great Skua (Stercorarius catarrhactes). Ann. Scot. Nat. Hist., I 894, pp. 8-I 2.

\section{3}

Scorpæna dactyloptera, Delaroche, and its Occurrence in the British North Sea Area. Proc. Roy. Phys. Soc. Edin., xii. pp. 94-IO I, Plate II. 



\section{892}

Note on the Rubecula tytleri of Jameson. The Ibis, I 892, pp. 558-559.

On the Rudimentary Hallux of the Kittiwake (Rissa tridactyla). The Ibis, I 902, pp. 442-447.

Report on the Great Skua (Stercorarius catarrhactes) in Shetland during the Season of 1891. Ann. Scot. Nat. Hist., I 892, pp. 87-92.

On Anarrhichas minor, Olafsen, and its Occurrence on the Aberdeenshire Coast. Ann. Scot. Nat. Hist., 1902, pp. 27-29, Plate I.

\section{89 I}

On the Occurrence of the Siberian Crane (Grus leucogeranus) in the Outer Hebrides. Scottish Naturalist, I 89 I, Pp. I 45-I 46.

On the Identity and Distribution of the Irish Rat (Mus hibernicus, Thompson). By W. Eagle Clarke and G. E. H. Barrett-Hamilton. Zoologist, i 89i, pp. I -9 .

\section{890}

On a Collection of Birds from Fort Churchill, Hudson's Bay. The $A u k$, i 890, pp. 319-322.

The Birds of Jan Mayen Island. Zoologist, i 890, pp. I- 6 and $4 \mathrm{I}-5 \mathrm{I}$.

\section{889}

On Mus hibernicus, the Irish Rat. Vertebrate Fauna of the Outer Hebrides, pp. 36b-36d, Plate.

On the Ornithology of the Valleys of Andorpa and the Upper Ariège, and other Contributions to the Avifauna of the Eastern Pyrenees. The Ibis, I 889, pp. $520-552$. 



\section{888}

Report on the Migration of Birds on the West Coast of

England and Wales in 1887. Report on the Migration of Birds, I 887, pp. 73-I I I.

\section{887}

The "Pinky" or "Scaly" of the Yorkshire Esk. Naturalist, I 887, p. 274.

Report on the Migration of Birds on the West Coast of England and Wales in 1886. Report on the Migration of Birds, i 886, pp. 79- I I 8.

\section{886}

Upper Nidderdale and its Fauna. Birds and Fishes. Naturalist, I 886, pp. 197-205.

Report on the Migration of Birds on the West Coast of England and Wales in 1885. Report on the Migration of Birds, i 885, pp. I 08 - I 3 I.

On the Occurrence of Sowerby's Whale (Mesoplodon bidens) on the Yorkshire Coast. By Thomas Southwell and W. Eagle Clarke. Ann. \& Mag. Nat. Hist., I 886, vol. i. pp. 53-59.

\section{5}

Report on the Migration of Birds on the West Coast of England and Wales in 1884. Report on the Migration of Birds, I 884, pp. I I-I 24 .

On the Occurrence of Sowerby's Whale (Mesoplodon bidens) on the Yorkshire Coast. By Thomas Southwell and W. Eagle Clarke. Naturalist, i 885, pp. $385-386$.

On the Occurrence of the Desert Chat (Saxicola deserti) in Yorkshire. Naturalist, I 885 , p. 387. 
On the Arrival of Summer Birds in the North of England in 1885. Naturalist, I 885, pp. 247-25 I.

On Birds observed in Eastern Iceland and the Faroes By W. Eagle Clarke and James Backhouse. The Ibis, I 885 , pp. 364-380, Plate IX.

\section{884}

On Birds observed in Slavonia and Hungary. The Ibis, I 884 , pp. I 2 5-1 48.

\section{88 I}

On the Occurrence of the Rustic Bunting (Emberiza rustica) in Yorkshire. Naturalist, I $881-82$, pp. $57-$ 58.

Bird-Life at the Farne Islands. Naturalist, I 88 I, pp. I-7.

\section{880}

The Birds of Yorkshire. Trans. Yorks. Nat. Union, I 880, pp. I-6o.

Ornithological Notes from Yorkshire. Zoologist, I 880 , pp. $353-358$.

Notes on Birds observed in Dutch Brabant. Naturalist, I 880, pp. 90-92 and 99-I07.

\section{9}

Yorkshire Ornithological Notes for 1878. Naturalist, I $878-79$, pp. I 77 -I 80 .

Notes on the Buzzard (Buteo vulgaris). Naturalist, I 879, pp. $49-53$.

In addition to the foregoing 74 Papers, several hundreds of Short Notes and Reviews. 



\section{N1

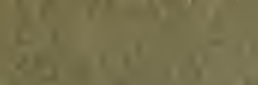

$(-0) 2$

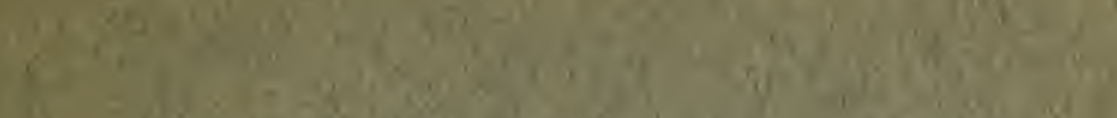

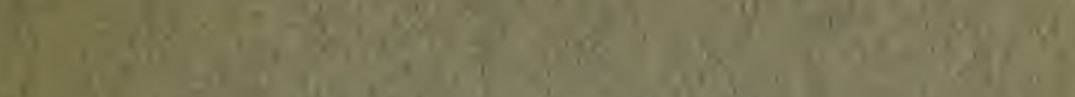

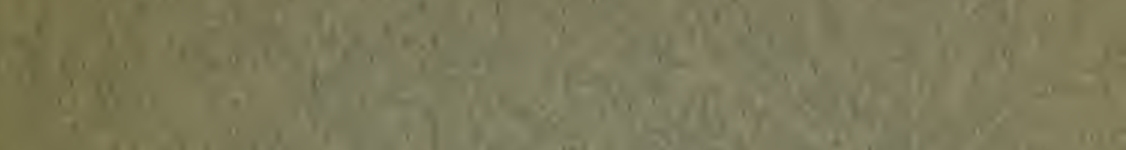

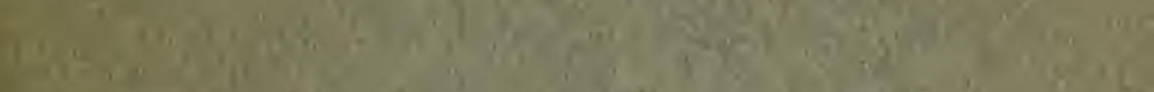

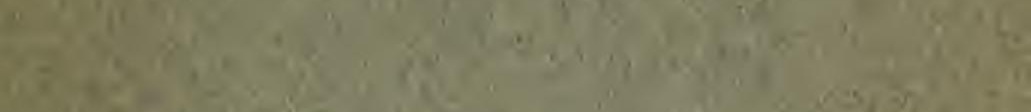

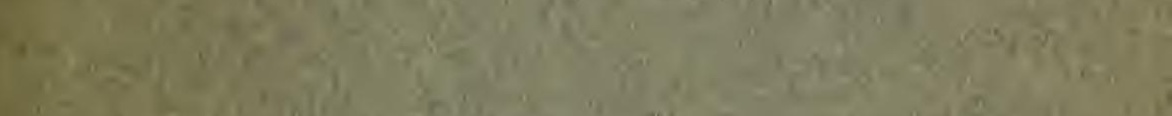

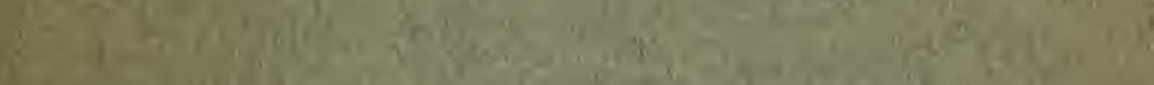

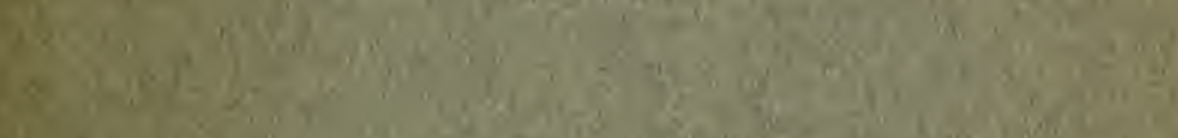

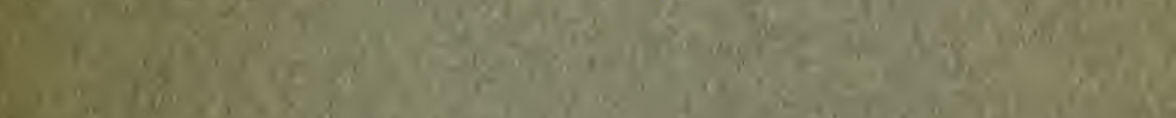

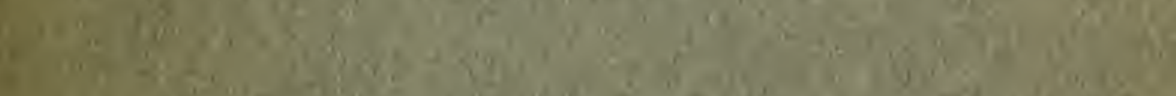

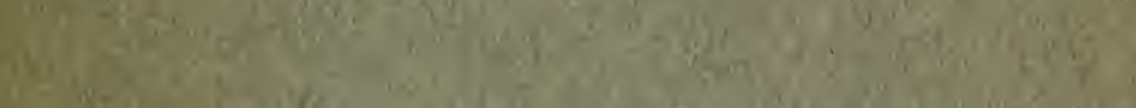
If

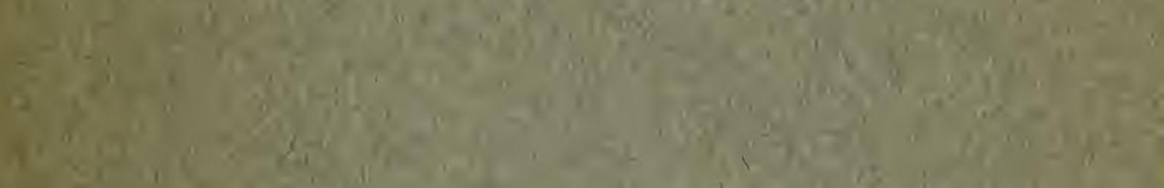

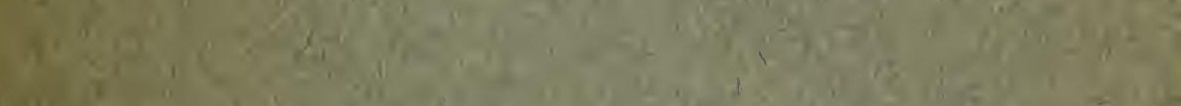

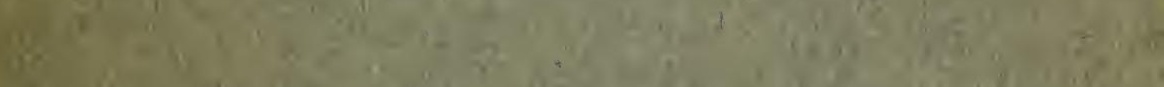

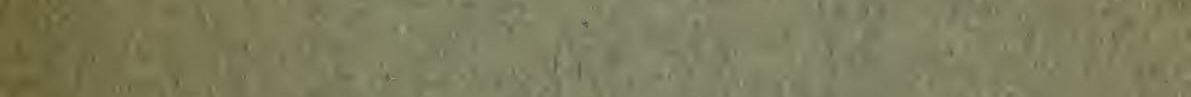

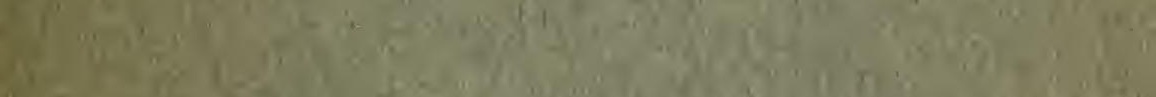

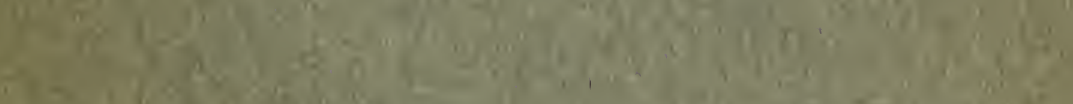

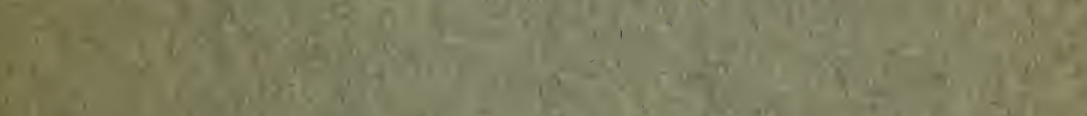

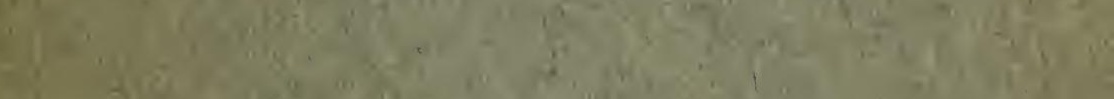

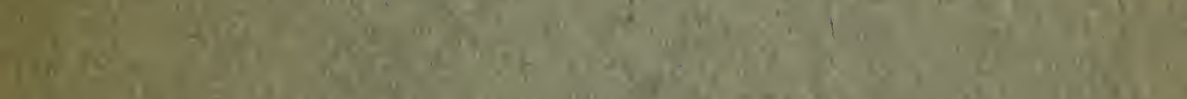

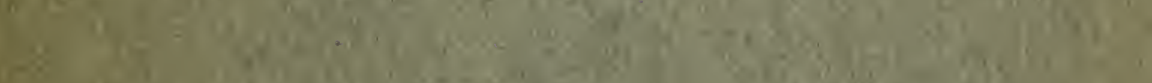
g.

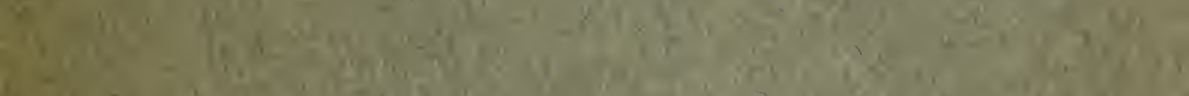

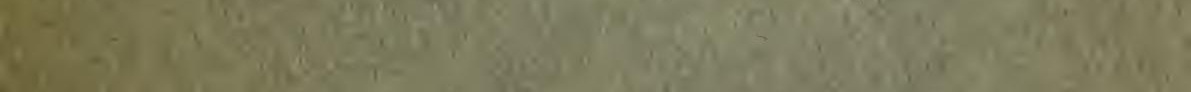

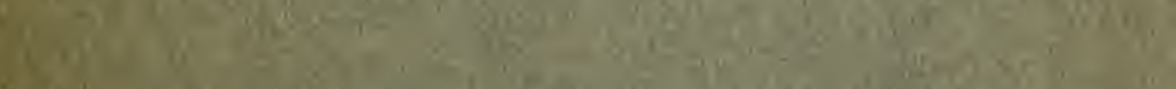

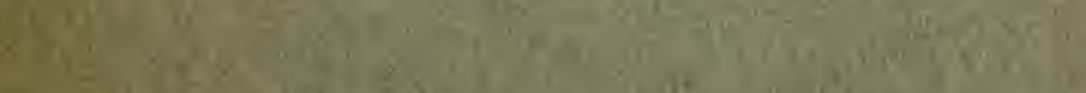

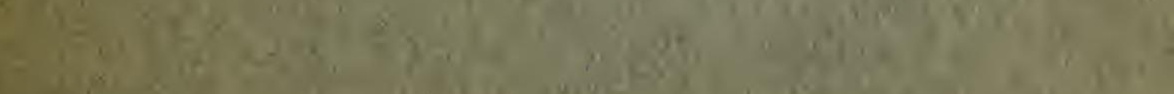

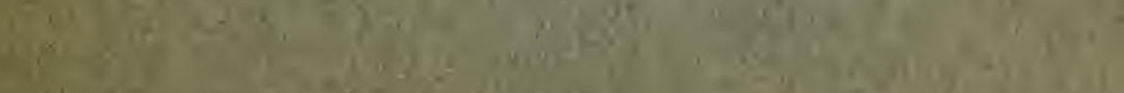

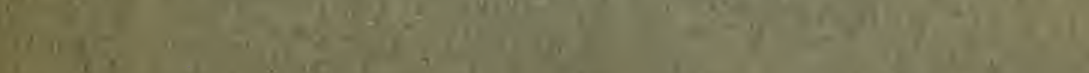

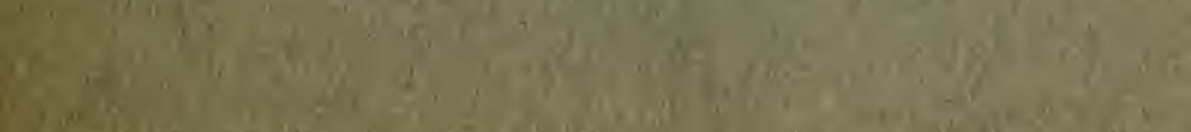
$3 w^{2}-8$

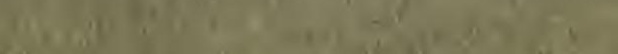




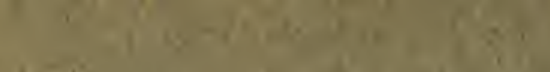

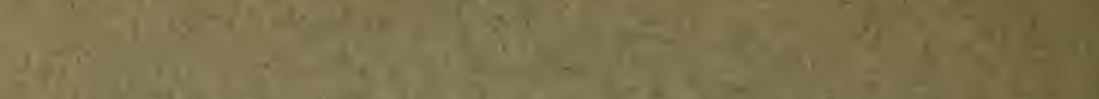

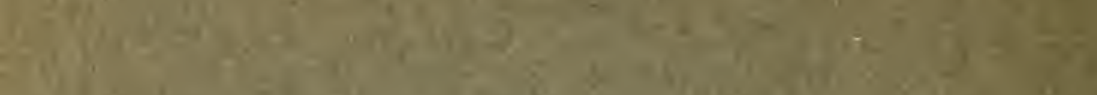

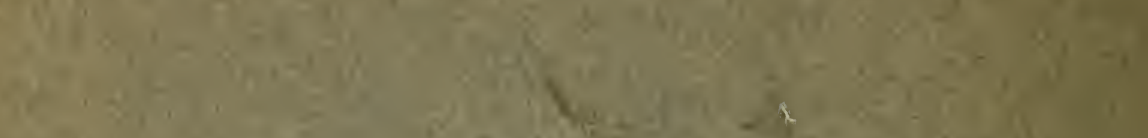

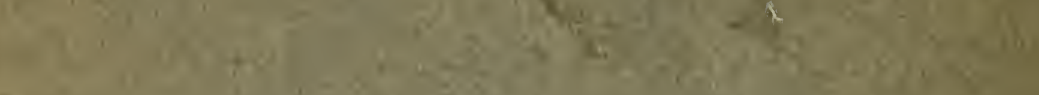

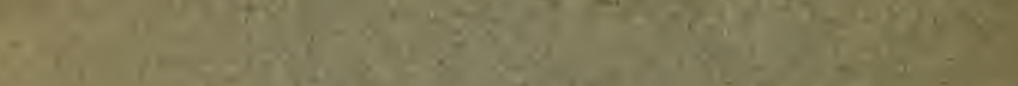

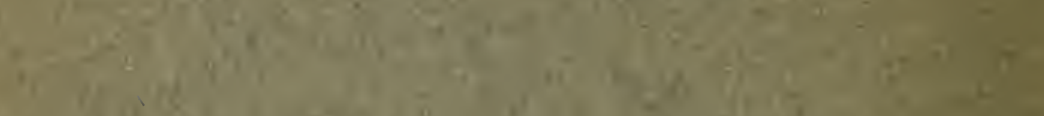

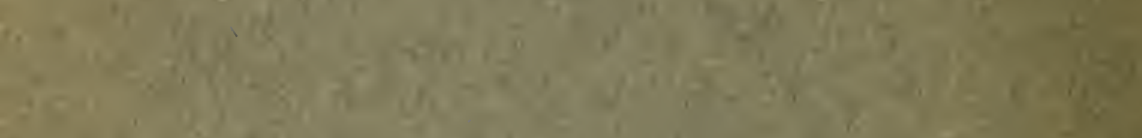

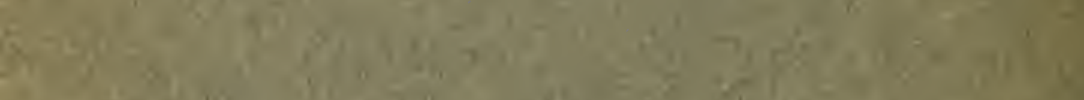

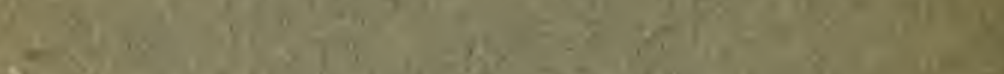

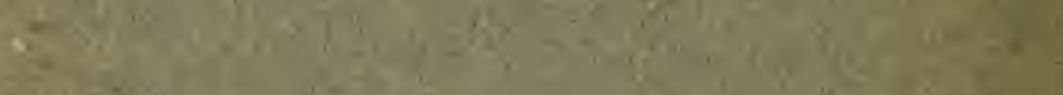

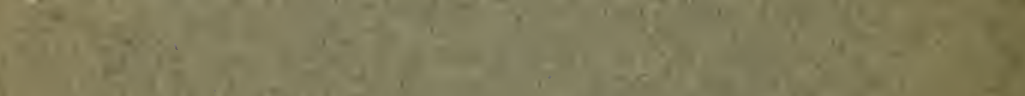

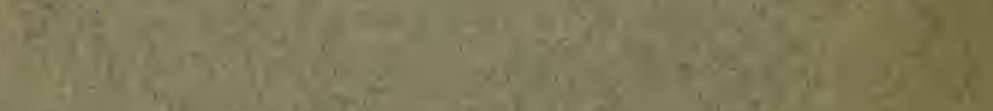

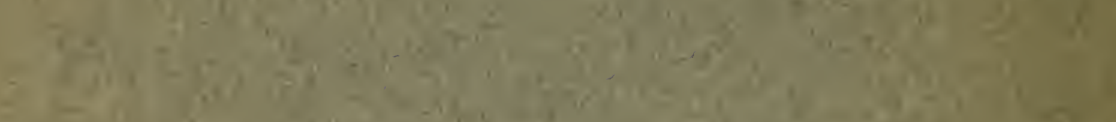

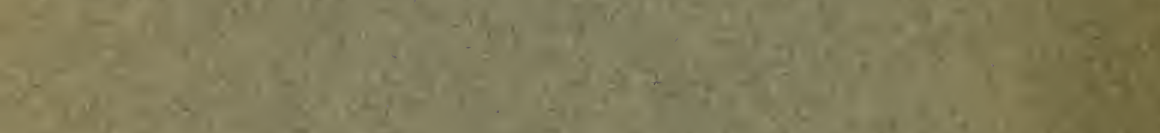

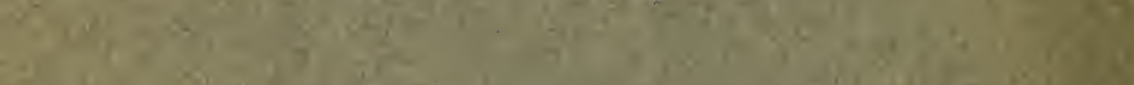

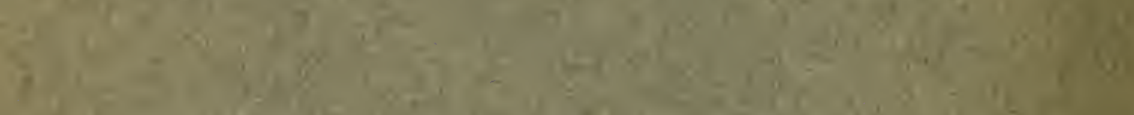

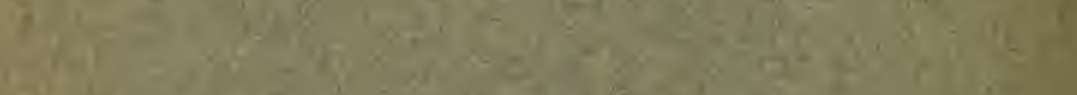

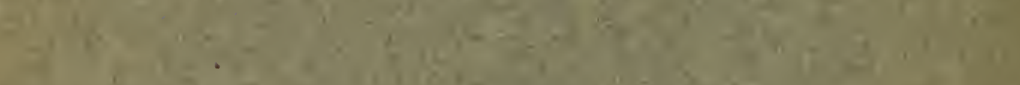

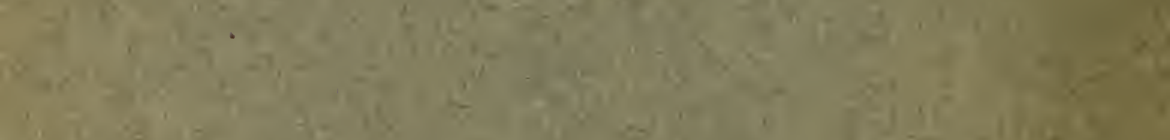

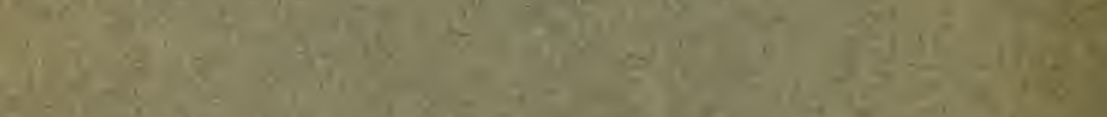

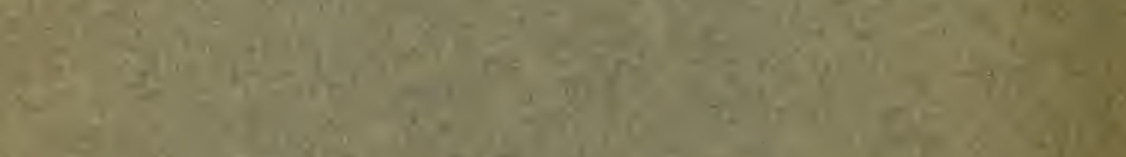

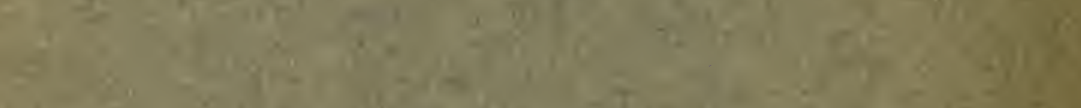

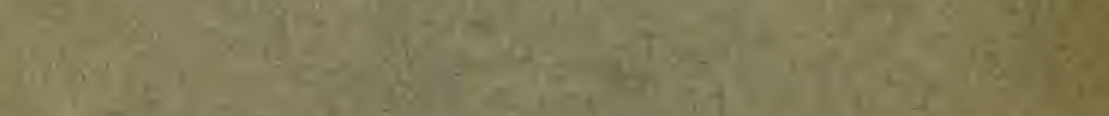

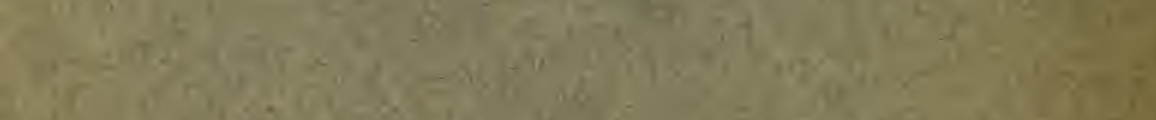

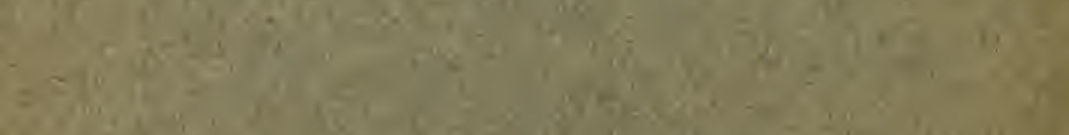

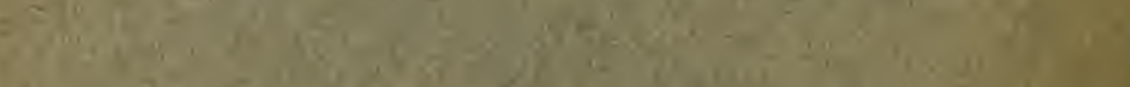

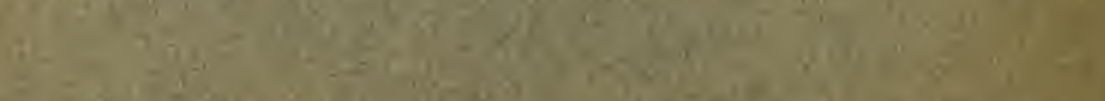
Sy

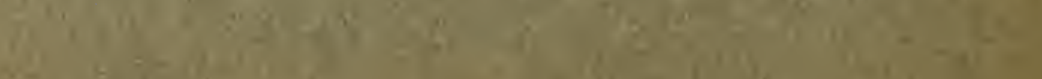



